\title{
Yazma Becerilerinin Geliştirilmesi Üzerine Hazırlanan Tezlere Yönelik Bir İnceleme: Yarı Deneysel Çalışmalar
}

DOI: 10.26466/opus.887374

\author{
$*$ \\ Ömer Kemiksiz* \\ * Dr. Öğr. Üyesi, Bartın Üniversitesi Eğitim Fakültesi, Bartın/Türkiye \\ E-Posta: okemiksiz@bartin.edu.tr \\ ORCID: 0000-0001-8628-6203
}

\begin{abstract}
Öz
Bu araştırmanın amacı yazma becerilerinin geliştirilmesi için yarı deneysel model kullanılarak hazırlanan lisansüstü tezlerin incelenmesidir. Nitel araştırma deseninde gerçekleştirilen çalışmanın verileri doküman incelemesi tekniği ile toplanmıştır. Araştırmanın örneklemi 2005-2020 yılları arasında hazırlanan ve yar deneysel model kullanılarak öğrencilerin yazma becerilerini geliştirmeyi amaçlayan 84'ü yüksek lisans ve 48'i doktora olmak üzere toplam 132 tezden oluşmaktadır. Veriler içerik analizi tekniği kullanılarak çözümlenmiştir. Araştırmanın bulgularına göre konuyla ilgili en fazla tezin 2019'da yayımlandığı belirlenmiştir. Öğrenim kademesine göre daha çok yüksek lisans düzeyinde hazırlandığı tespit edilen araştırmaların en fazla hazırlandı̆̆ $ı$ kurumlar Gazi Üniversitesi ile Ankara Üniversitesidir. Tezlerin daha çok Türkçe eğitimi bilim dallarında hazırlandığı görülürken tez danışmanlarında yüksek lisans için "Dr. Öğr. Üyesi" ve "Doç. Dr.", doktora için "Prof. Dr." unvanlı akademisyenlerin ön planda olduğu tespit edilmiştir. Araştırmaları örneklem gruplarında ortaokul öğrencileri daha çok tercih edilmiş, en çok kullanılan bağımsız değişkenlerin yazma yöntem/teknikleri olduğu ortaya çıkmıştır. Ön test-son test kontrol gruplu desenler araştırmalarda sıkça kullanılmış, çalışma gruplarında genel olarak 11-40 kişilik gruplarla çalışılmış ve araştırmaların uygulamaları daha çok 5-8 ile 9-12 hafta sürmüştür.
\end{abstract}

Anahtar Kelimeler: Dil becerileri, yazma becerisi, lisansüstü tezler, yarı deneysel çalı̧̧malar. 


\title{
A Study on Theses Written on Improving Writing Skills: Quasi-Experimental Studies
}

\begin{abstract}
The aim of this research is to analyze the postgraduate theses written by using a quasi-experimental model to improve writing skills. The data of the study, which was carried out in qualitative research design, were collected through document analysis technique. The sample of the study consists of 132 theses in total as being 84 master's theses and 48 doctoral theses, which were carried out between 2005 and 2020 and aimed to improve writing skills of students by using quasi-experimental model. The data were analyzed using the content analysis technique. According to the findings of the research, it was determined that the highest number of theses on the subject were published in 2019. It was detected that while studies were carried out at master's level the most in terms of educational level, Gazi University and Ankara University are the institutions where the highest number of research was carried out. While it was observed that theses were mostly prepared in the field of Turkish education, it was identified that thesis advisors for master's theses were mostly scholars with the title of "Dr." and "Assoc. Prof. Dr." and thesis advisors for doctoral theses were mostly scholars with the title of "Prof. Dr.". Secondary school students were preferred more in the sample groups of the studies, and it was revealed that the most used independent variables were writing methods/techniques. Pretest-posttest control group designs were frequently used in the studies; in general, groups consisting of 11-40 people were studied in the study groups, and the implementation of the studies mostly took 5-8 and 9-12 weeks.
\end{abstract}

Keywords: Language skills, writing skill, postgraduate theses, quasi-experimental studies. 


\section{Giriş}

Kendini anlatmak ve başkalarını anlamak insanoğlunun en temel istek ve ihtiyaçlarındandır. Bu sebeple kişilerin günlük hayatlarının önemli bir bölümü diğer birey veya gruplarla iletişim kurarak geçer. Bu iletişimler esnasında da karşı tarafa mesajları ulaştırmak için çeşitli iletişim kanallarına başvurulur. Özellikle aynı ortamın paylaşılmadığı kişilerle diyalog kurmada, resmî işlemlerde ve geleceğe kalıcı ürünler bırakmada tercih edilen bu kanallardan biri de temel dil becerilerinin anlatma boyutunda yer alan yazi/yazmadir.

Dil üretiminde önemli bir beceri (Fareed, Ashraf ve Bilal, 2016) olan, daha çok doğal bir süreçle kazanılan dinleme ve konuşmanın ardından belli bir eğitimle okuma becerisiyle beraber öğrenilen (Zorbaz, 2014) ve dört temel dil becerisinin son halkası (Demirel, 2000) kabul edilen yazma becerisiyle ilgili araştırmacılar tarafından çeşitli tanımlamalar yapılmıştır. Yaman'a (2013, s.83) göre yazma "düşündüklerimizi, duyduklarımızı, gördüklerimizi, hayallerimizi, hissettiklerimizi, kısacası yaşadıklarımızı birtakım semboller aracılığıyla başkalarına anlatma işi"dir. Öz (2011, s.251), yazmayı "beyinde yapılandırılmış bilgilerin yazıya dökülmesi işlemi" şeklinde ifade ederken Adalı'ya (2016, s.30) göre bu beceri "sözlü iletişim aracı olan dili, yazı denilen görsel ve tek boyutlu bir dizgeye aktarma eylemi" dir. Yazmaya daha geniş bir çerçeveden bakan Topuzkanamış (2014, s.12) ise beceriye "insanın zihinsel üretimleri olan duygu, fikir, istek, hayal, gözlem, izlenim, yaşam, yaşantı gibi olguların muhataba iletilmesi gayesiyle insan tarafından geliştirilmiş olan dil ve onun aletleri olan alfabe, yazı ve noktalama işaretleri aracılığıyla ilkel veya gelişmiş bazı teknolojik olanaklarla ağaca, taşa, kuma, havaya, metale, yaprağa, kâğıda veya sanal ortama iz bırakması işi" şeklinde bir tanım getirmektedir. Yazılı anlatım becerisinin, günlük yaşamımızın hemen hemen her alanında önümüze çıktığını vurgulayan Özbay'a (2005) göre yazı, bireylerin birbirleriyle iletişim kurmak için kullandıkları dil denilen sistemi, belli semboller ağıyla gösteren ikinci bir sistem, diğer bir ifadeyle sözün resimleştirilmiş şeklidir.

“Çağlar boyunca yazılı iletişim, toplumların gelişmişlik düzeyini gösteren önemli etkenlerden biri olmuştur. Gelişmişlik düzeyi yüksek top- 
lumlarda yazılı iletişim de fazladır. Nitekim teknolojik gelişmeler sonucunda artan iletişim araçlarında yazılı anlatımın ağırlık kazandığı görülmektedir" (Coşkun, 2014, s.50). Bu durumun teknolojik gelişmelere paralel olarak ilerleyen süreçte daha da önem kazanacağ 1 düşünüldüğünde bireylerin bu beceriyi kazanmaları ve etkili bir şekilde kullanmaları birçok avantajı beraberinde getirecektir. "Yazılı anlatım becerisini kazanmak, kişinin günlük gereksinimlerini karşılaması, eğitimini sürdürmesi, hayatında başarılı olması, anlama ve anlatma yeteneğini yükselterek insanları anlayan ve insanlar tarafından anlaşılan biri olması için gerekli" (Arıcı ve Ungan, 2015, s.4) olduğu kadar "insanların gördüklerini, düşündüklerini, yaşadıklarını, hayallerini, isteklerini amacına uygun bir şekilde dile getirme becerisi kazanmaları, onların akademik ve sosyal hayatta da daha başarılı olmalarına zemin hazırlamaktadır" (Maden, 2011, s.1528). Yazma becerisinin öğretim sürecinde öğrenmeyi pekiştirmeye yönelik ödev ve proje gibi görevleri başarılı bir şekilde yerine getirmeyi sağladığını dile getiren Karatay (2015), yazılı anlatım becerisinin hem öğretim sürecinde yazılı sınavlarda başarılı olmanın hem de günlük hayatta kendini ifade etmenin anahtarı olduğuna dikkat çekmektedir. Kellogg ve Raulerson'a (2007) göre de etkili yazma becerileri hem yükseköğretimde hem de takip eden iş dünyasında merkezî bir konumdadır. Bundan dolayı öğrencilerin gerek eğitim gerek istihdam konusundaki gereksinimlerini yerine getirebilmeleri için iyi bir yazma becerisine ihtiyaçları vardır (Durga ve Rao, 2018). Yazmanın, iletişim kurma, öğrenme ve kendini ifade etme için değerli bir araç olduğunu belirten Orhan-Karsak'a (2020) göre yeterli yazma becerisine sahip olamayan öğrenciler gerek eğitim öğretim sürecinde gerekse mezuniyet sonrası meslek hayatında istihdam sürecinde dezavantajlı durumlarla ve kısıtlı fırsatlarla karşılaşabilirler. Bu nedenle insanlarla iletişim kurmak için kişisel, onlara bilgi ve yön vermek, onları aydınlatmak için toplumsal, hangi mesleği yaparsak yapalım yazma zorunda olduğumuz için uğraşsal bir ihtiyaç olarak görülen (Arıcı ve Ungan, 2015) bu becerinin küçük yaşlardan itibaren kazandırılması önem arz etmektedir. Bu becerinin kazanılması/kazandırılması sürecinde de birtakım ilkelere uygun hareket edilmesi hedeflenen başarıya ulaşılmasında yararlı olacaktır. 
El ve göz eğitimine dayanmakla beraber uzun süreli bir alıştırma sonucu kazanılan (Gündüz ve Şimşek, 2016) yazma becerisinde teknik bilgiye sahip olmak yeterli değildir. Bilginin beceri olarak da sergilenmesi gerekir. Metin üretmeksizin, metin üretim sürecini içselleştirmek ve teorik bilginin işe yararlılığını görmek son derece zordur (Göçer, 2014). Bunun için yazılı anlatımda yalnızca kuralları öğrenmek değil bunların yazıya aksettirilmesi de işin önemli bir boyutunu oluşturur. Yani öğrendiklerimizi doğru, kolay, pürüzsüz ve inandırıcı bir anlatım tarzı ile yazıya yansitabilmek için uygulamaya yönelmek şarttır (Aktaş ve Gündüz, 2004). Temur ve Çakıroğlu'na $(2015$, s.12) göre "yazılı anlatım becerisinin geliştirilmesi süreç odaklı bir eğitimle mümkündür. Etkili tasarlanmış bir süreç öğrencilerin sadece yazma becerilerinin değil bilişsel becerilerinin de gelişimine de katkı sunacaktır. Zira yazma görünüşte kalem ve kâğıt etkileşiminden ortaya çıkan bir ürün gibi görünse de ifade edilmek istenen fikirler, hayaller, tasarılar, duygular öncelikle zihinsel bir süreçten geçmektedir. Yazmanin hem dil becerileri hem de zihinsel becerilerin gelişimine katkı sağladığını vurgulayan Güneş'e (2020) göre bu beceri öğrencilerin bilgilerini düzenleme, düşüncelerini genişletme, bilgi birikimini zenginleştirme ve zihinsel sözlüklerini geliştirmelerine yardımcı olmaktadır. Aynı zamanda dili kullanma, düşünceleri yazıya aktarma ve somutlaştırmaya izin veren bir süreç olması yönüyle yazma, öğrencinin zihinsel gelişimi açısından büyük önem taşımaktadır. Akyol'a (2006) göre yazma becerileri gelişen çocuğun bilgiyi transfer etme, düşünceleri gözden geçirip düzenleme becerileri de gelişmektedir. Ayrıca yazma eğitimi kendi içerisinde yaratıcı düşünme, araştırma becerisine sahip olma, eleştirel düşünme, problem çözme becerisini elde etme, Türkçeyi güzel kullanma gibi faaliyetleri bir arada organize etmeyi gerektirdiğinden (Maden, 2011) yazma becerisi sadece sesleri ve sözcükleri gösteren işaretlerle cümleler üretmek değil, bellekte tasarlanan düşüncelerin alıcının anlayacağı bir biçimde ve tam olarak tasarlandığı şekilde iletilebilmesidir (Dilidüzgün, 2020). Bundan dolayı "yazma becerisini mekanik değil, eleştirel bir düşünme süreci olarak algılamak ve bilmek gerekir" (Demirel, 2000, s.71).

Yazma becerilerinin geliştirilmesinde teorik bilgiden ziyade uygulamaya dönük çalışmalara ağırlık verilmesi, yazma eğitiminin en önemli aşamalarındandır. Öğrencilere yazma becerisi kazandırmanın ilk ve en 
önemli basamağının öğrencilerde yazma isteği uyandırmak olduğunu belirten Gündüz ve Şimşek'e (2016) göre öğretmen, başlangiçta yazmaya karşı ürkek ve çekingen davranan öğrencileri çeşitli telkinlerle cesaretlendirmeli ve onlara öz güven kazandırmalıdır. Öğrencilere yapılacak bu tür yüreklendirmeler ve yönlendirmelerle ilk önce onlarda yazmaya karşı olumsuz bir tutum varsa o giderilmiş olacak, daha sonra da kendi yeteneklerini tanıyarak yazmayı, severek yapacakları bir iş olarak görmeleri sağlanacaktır (Göçer, 2014). Sever'e (2011) göre öğrencilerde yazma ilgi ve isteğinin oluşturulmasında temel sorumluluk ise Türkçe öğretimine düşmektedir. Bu sorumluluk, öğrencilere düzenli düşünme ve yazma alışkanlığ1 kazandırma gibi temel bir amaçla bütünleşmektedir. Öğrencilerin yazma becerilerinin geliştirilebilmesi için öğretmenlere önemli görevler düştügünü dile getiren Şengül'e (2011) göre öğretmenlerin, yazma eğitiminin genel amaçları ve öğretim süreci içerisinde öğrencilerin sahip olmaları ön görülen kazanımlar hakkında bilgi sahibi olmaları ve bu kazanımları öğrencilerde ölçülebilir bir yapıya dönüştürmeleri gerekir. Yine öğrenciler bu süreçte kendilerini yazılı olarak ifade edebilmenin, yazı yazmanın herkeste var olmayan sadece bazı kişilere has bir beceri olmadiğına, yazma tecrübeleri, çalışmaları ile geliştirilebilen bir beceri olduğuna ikna edilmeli (Karatay, 2015) ve yazma eğitimi uzun zamana yayılması gereken, sabır isteyen bir süreç olduğundan öğrencileri başlangıçta yıldırmamak ve yazma isteklerine ket vurmamak için kolaydan zora, basitten karmaşığa doğru bir yol izlenmelidir (Gündüz ve Şimşek, 2016). Kellogg'a (2008) göre yazma becerisi tipik olarak yirmi yıldan fazla bir süre içerisinde gelişir, öğrenciler bu beceriyi geç ergenlik döneminden yetişkinliğe kadar öğrenir ve olgunlaştırır. Bu sebeple yazma çalışmalarında öğrencilerden kısa bir süre içerisinde başarı beklemenin doğru bir yaklaşım olmayacağı söylenebilir.

Yazma eğitiminde temel alınacak ilkeleri belirlemek, öğrencileri yazmaya karşı motive etmek kadar yazma etkinliklerinde farklı uygulamalara gitmek de bu becerinin geliştirilmesinde büyük önem taşır. Yazma problemi olan öğrencilerin belli bir plana göre çalışma yapmadığını vurgulayan Okasha ve Hamdi'ye (2014) göre bu öğrenciler, yazmaya yalnızca içerik üretimi olmak üzere tek bir süreci içeriyormuş gibi yaklaşırlar. Oysaki yazma birbirinden bağımsız ve sıralı aşamaları içeren basit bir etkin- 
lik değil tam tersine etkileşimli (Alodwan ve Ibnian, 2014) ve yazarın değişkenlerin eş zamanlı kontrolünü gerektiren son derece karmaşık bilişsel bir etkinliktir (Durga ve Rao, 2018). Zira yazılacak metin kâğıttan önce beyinde yapılandırılmakta, yazılacak konuyla alakalı akla gelen duygu ve fikirler beyinde sınırlandırmaya, sinıflandırmaya, sıralamaya tabi tutularak düzenlenmektedir (Coşkun, 2014). Bu yönüyle insan beyninin bütün inceliklerinin keşfedildiği bir yaratım süreci olan yazma, beyindeki karışık düşüncelerin düzenlenmesini ve berraklaşmasını sağlayan önemli bir çıktı olarak algılanmaktadır (Karadağ, 2020). Bu sebeple yazılı anlatım derslerinde öğrencilerin, fikirlerini mantıksal bütünlük içinde yazma, farklı düşünmeye yönlendiren ifadeleri kullanma, kıyaslama yapma, neden-sonuç ilişkisi kurma, sınıflama, değerlendirme, özetleme gibi anlamayı ve zihinsel becerileri geliştirici çalışmalar yapmalarının önemine değinen Güneş (2014), bununla birlikte eğlenmek ve bilgi edinmek için yazma, eleştirel, ikna edici, betimleyici ve serbest yazma gibi çeşitli tür, yöntem ve tekniklere de yer verilmesi gerektiğini vurgulamaktadır. Yazma çalışmalarında öğrencinin sürekli takip edilip ona yol gösterilmesi, bireysel farklılıkların dikkate alınması, yazılarda biçimden ziyade içeriğe öncelik verilmesi, öğrencilerin tek bir konu üzerinde yazmaya zorlanmayıp onlara konu seçme hakkı tanınması, yazma çalışmalarının mümkün olduğunca farklı metin türleri üzerinde yaptırılması ve yalnızca okuldaki etkinliklerle sınırlandırılmaması (Coşkun, 2014), öğrencilere yazdıkları ile ilgili dönüt verilmesi, yazılarını sınıfta birbirleriyle paylaşmalarının sağlanması (Karatay, 2015) da yazma eğitiminde mutlaka dikkat edilmesi ve uygulanması gereken hususlardandır.

Türkçe Dersi Öğretim Programı'nda (MEB, 2019) da yazma becerisinin önemine değinilmiş ve Program'ın amaçları arasında öğrencilerin "dinleme/izleme, konuşma, okuma ve yazma becerilerinin geliştirilmesi", "Türkçeyi, konuşma ve yazma kurallarına uygun olarak bilinçli, doğru ve özenli kullanmalarının sağlanması", "okuma yazma sevgisi ve alışkanl1ğını kazanmalarının sağlanması" ve "duygu ve düşünceleri ile bir konudaki görüşlerini veya tezini sözlü ve yazılı olarak etkili ve anlaşılır biçimde ifade etmelerinin sağlanması"na yer verilmiştir. Buna göre bütün bireylerin öğrenim hayatları boyunca kendilerini yazılı olarak güzel, etkili ve doğru bir şekilde ifade edebilecek seviyeye gelmeleri/getirilmeleri Türkçe eğitiminin en öncelikli amaçları arasındadır. 
Akademik ve sosyal hayattaki başarıda son derece önemli ve etkili olan yazma becerisi, bilimsel çalışmalarda da araştırmacıların dikkatini çeken ve üzerinde çok sayıda araştırma yapılan bir dil becerisi olarak öne çıkmaktadır. Yağmur-Şahin, Kana ve Varışoğlu'nun (2013) Türkçe eğitimi alanında 2000-2011 yılları arasında yapılan lisansüstü tezleri inceledikleri araştırmada temel dil becerileri içerisinde en fazla çalışılan becerinin (f=59) yazma becerisi olduğu belirlenmiştir. Türkçe eğitimi alanında 19952018 yılları arasında hazırlanan doktora tezlerini inceleyen Boyacı ve Demirkol (2018) ile 2005-2010 yılları arasında hazırlanan yüksek lisans tezlerini inceleyen Sevim ve İşcan'ın (2012) araştırmalarında yazma becerisinin araştırmacılar tarafından diğer becerilere oranla daha fazla tercih edildiği sonucuna ulaşılmıştır. Bozkurt ve Uzun (2015) tarafından yapılan araştırmada Türkçenin eğitimi öğretimi alanındaki bilimsel toplantılarda (2008-2013 yılları) sunulan bildirilerin konu dağılımlarında temel dil becerileri içerisinde ilk sırayı (\%29) yazma becerisi almıştır. Türkçe eğitiminde eylem araştırmasıyla gerçekleştirilen çalışmaları inceleyen GülenCanlı ve Tepeli'nin (2019) araştırmasında bu yöntemin en fazla yazma becerisinin geliştirilmesinde kullanıldığ Türkçe öğretmeni adayları olan ve 2014-2018 yılları arasında yayımlanan makalelerin konu dağılımlarını inceleyen Arı, Yaşar ve İstanbullu'nun (2020) araştırmasında da yazma becerisinin, temel dil becerileri içerisinde en fazla çalışılan beceri olduğu $(\% 19,6)$ ortaya çıkmıştır. Ayrıca Özçakmak (2017) tarafından gerçekleştirilen araştırmada 2011-2015 arasında Türkçe eğitimi alanında hazırlanan tezlerde yazma becerisinin, okuma becerisinden sonra en çok çalışılan dil becerisi olduğu tespit edilmiştir. Coşkun, Özçakmak ve Balcı'nın (2012) araştırmasında Türkçe eğitimiyle ilgili 1981-2010 yılları arasında hazırlanan tezlerde; Varışoğlu, Şahin ve Göktaş'ın (2013) araştırmasında da Türkçe eğitimiyle ilgili 2000-2011 yılları arasında yayımlanan makalelerde benzer bir bulguya ulaşılmıştır. Bunun dışında yalnızca yazma becerisiyle ilgili makale (Göksu, 2016; Karagöz ve Şeref, 2020; Tok ve Potur, 2015) ve tezlerdeki (Coşkun, Balcı ve Özçakmak, 2013; Elbir ve Yıldız, 2012; Göksu, 2016; Temizkan ve Erdevir, 2020; Uyar, 2016) eğilimleri ortaya çıkarmayı hedefleyen araştırmaların mevcudiyeti de bu becerinin önemini göstermesi bakımından dikkate değerdir. 
$\mathrm{Bu}$ araştırmanın amacı yarı deneysel modelin kullanılarak öğrencilerin yazma becerilerinin geliştirilmesini hedefleyen çalışmaları farklı değişkenlere göre incelemektir. Bu amaç doğrultusunda çalışmanın araştırma soruları aşağıdaki şekilde oluşturulmuştur:

1. Yazma becerilerinin geliştirilmesi üzerine hazırlanan tezlerin yıllara göre dağılımı nasıldır?

2. Yazma becerilerinin geliştirilmesi üzerine hazırlanan tezlerin öğrenim kademesine göre dağılımı nasıldır?

3. Yazma becerilerinin geliştirilmesi üzerine hazırlanan tezlerin hazırlandıkları üniversitelere göre dağılımı nasıldır?

4. Yazma becerilerinin geliştirilmesi üzerine hazırlanan tezlerin hazırlandıkları bilim dallarına göre dağılımı nasıldır?

5. Yazma becerilerinin geliştirilmesi üzerine hazırlanan tezlerin danışman unvanlarına göre dağılımı nasıldır?

6. Yazma becerilerinin geliştirilmesi üzerine hazırlanan tezlerin çalışma gruplarına göre dağılımı nasıldır?

7. Yazma becerilerinin geliştirilmesi üzerine hazırlanan tezlerin bağımsız değişkenlere göre dağılımı nasıldır?

8. Yazma becerilerinin geliştirilmesi üzerine hazırlanan tezlerin yarı deneysel yöntemlere göre dağılımı nasıldır?

9. Yazma becerilerinin geliştirilmesi üzerine hazırlanan tezlerin deney grubundaki katılımcı sayısına göre dağılımı nasıldır?

10. Yazma becerilerinin geliştirilmesi üzerine hazırlanan tezlerin uygulama sürelerine göre dağılımı nasıldır?

\section{Yöntem}

Bu bölümde araştırmanın modeli, örneklemi, verilerin toplanması ve analiziyle ilgili açılamalara yer verilmiştir.

\section{Model}

Yazma becerilerinin geliştirilmesi amacıyla yarı deneysel modeller kullanılarak gerçekleştirilen lisansüstü tez çalışmalarını çeşitli yönlerden incelemeyi amaçlayan bu çalışma nitel araştırma deseninde yürütülmüştür. Nitel araştırma, Yıldırım ve Şimşek (2011) tarafından gözlem, görüşme ve 
doküman analizi gibi nitel veri toplama yöntemlerine başvurulan, alg1 ve olayların doğal ortamda gerçekçi ve bütüncül şekilde ortaya konması amacıyla nitel bir sürecin takip edildiği araştırma türü şeklinde tanımlanmaktadır.

\section{Örneklem}

Araştırmanın örneklemini 2005-2020 yılları arasında hazırlanan ve yazma becerilerinin geliştirilmesinde yarı deneysel desenin kullanıldığı yüksek lisans ve doktora tezleri oluşturmaktadır. Tez çalışmalarının daha geniş bir zaman dilimine yayılan ve uygulamaya dönük çalışmalara sıkça yer verilen araştırmalar olması, bu araştırmada örneklem olarak lisanüstü tezlerin tercih edilmesinde etkili olmuştur. Bu sınırlılığa dayalı olarak araştırmada amaçsal örnekleme çeşitlerinden ölçüt örnekleme kullanılmıştır. $\mathrm{Bu}$ örnekleme çeşidinde gözlem birimleri belli özelliklere sahip şahıslar, olaylar, durumlar ve nesnelerden oluşur. Böyle bir durumda belirlenen ölçütü karşılayan birimler örnekleme dâhil edilirler (Büyüköztürk, KılıçÇakmak, Akgün, Karadeniz ve Demirel, 2020). Araştırmada örneklem ölçütü olarak çalışmaların "lisansüstü tez" şeklinde "2005-2020 yıllarından birinde hazırlanması", temel dil becerilerinden "yazma" ile sinırlı olması ve araştırma yönteminde "yarı deneysel desen"in kullanılması belirlenmiştir.

\section{Verilerin Toplanması ve Analizi}

Araştırma verilerinin toplanmasında nitel araştırmaların veri toplama tekniklerinden biri olan ve araştırılması amaçlanan olgu veya olaylar hakkında bilgi içeren yazılı materyallerin analizini kapsayan (Yıldırım ve Şimşek, 2011) doküman incelemesinden yararlanılmıştır. Veriler, 2020 yılı aralık ayı içerisinde YÖK Tez Merkezinden "yazma", "yazma eğitimi", "yazılı anlatım" anahtar kelimeleri kullanılarak toplanmış, erişime açık olan tezler araştırma kapsamına alınmıştır. Araştırmaların incelenmesinde kullanılmak üzere araştırmacı tarafından Yayın Sınıflandırma Formu hazırlanmış, formun kapsam geçerliği için bir Türkçe eğitimi ve bir eğitim bilimleri alan uzmanının görüşlerine başvurulmuştur. Alınan görüşler doğrultusunda son şekli verilen form, araştırma sorularına uygun 
olacak biçimde tezlerin "yayın yılı", "öğrenim kademesi”, "hazırlandığ üniversite", "hazırlandığı bilim dalı", "danışman unvanı", "çalışma grupları", "bağımsız değişkenleri", "çalışma yöntemi", "katılımcı sayısı" ve "uygulama süresi" şeklinde 10 maddeden oluşmuştur. Tezlerin incelenme aşamasında ulaşılan veriler bu maddelerin altına kodlanmıştır.

Araştırma verilerinin analizinde içerik analizi tekniğinden yararlanılmıştır. Bu teknik belli kurallara dayalı kodlamalar yoluyla bir metne ait kelimelerin daha küçük içerik kategorileriyle özetlendiği sistemli ve yinelenebilir bir tekniktir (Büyüköztürk, Kılıç-Çakmak, Akgün, Karadeniz ve Demirel, 2020). Araştırmada örnekleme alınan tezler yayın yılı, öğrenim kademesi, hazırlandığı üniversite, hazırlandığı bilim dalı, danışman unvanı, çalışma grupları, bağımsız değişkenler, yöntem, katılımcı sayısı ve uygulama süresi temaları bakımından tasnif edilmiş, bu temalara göre elde edilen bulgular sıklık (f) ve yüzde (\%) değerleri hesaplanarak tablolar ve grafikler aracılığıyla aktarılmıştır.

Geçerlik ve güvenirlik, nitel araştırmaların önemli kavramlarındandır. Bu tür araştırmaların geçerliğini sağlamada araştırmacıdan hem veri toplama hem de toplanan bu verilerin analiz edilmesi ve yorumlaması aşamalarında tutarlı olması, ayrıca bu tutarlığı nasıl sağladığını izah etmesi beklenir (Yıldırım ve Şimşek, 2011). Bu araştırmada geçerliği sağlamak için sürecin ne şekilde yürütüldüğüyle ilgili bilgiler aktarılarak okurun bilgilendirilmesi amaçlanmış ve Bulgular bölümünde tablo-metin/grafikmetin uyumuna dikkat edilmiştir.

Verilerin analizinde başka bir araştırmacının görüşlerini alarak sonuçları teyit yoluna gitme (Yıldırım ve Şimşek, 2011) nitel çalışmalarda güvenirliği oluşturma yollarından biridir. Araştırmada analize tabi tutulan tezlerden rastgele seçilen 40 tanesi için başka bir araştırmacının görüşüne başvurulmuş ve aradaki uyuma bakılmıştır. Miles ve Huberman, [Güvenirlik = (Görüş Birliği/ (Görüş Birliğgi + Görüş Ayrılığı) X 100] formülü kullanılarak gerçekleştirilecek işlem neticesince sonucun \%90' a yakın veya bunun üzerinde olduğunda kabul edilebilir olduğunu önerdiklerinden (Büyüköztürk, Kılıç-Çakmak, Akgün, Karadeniz ve Demirel, 2016) ve yapılan hesaplama sonucu uyum oranının \%94 olmasından dolayı ulaşılan sonuçların güvenilir olduğu düşünülmektedir. 


\section{Bulgular}

Bu bölümde araştırma sorularından hareketle çalışmada ulaşılan bulgulara değinilmiştir.

\section{Birinci Araştırma Sorusuna Yönelik Bulgular}

Araştırmanın "Yazma becerilerinin geliştirilmesi üzerine hazırlanan tezlerin yıllara göre dağılımı nasıldır?" şeklindeki birinci sorusuna yönelik bulgulara Grafik 1'de yer verilmiştir.

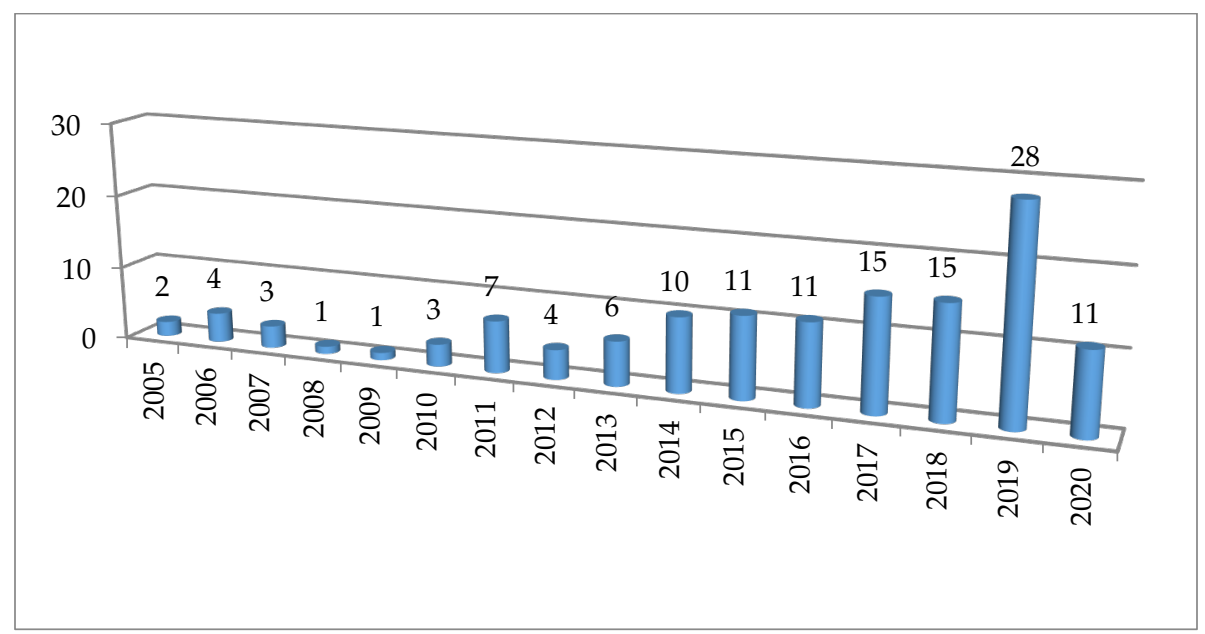

Grafik 1. Yazma becerilerinin geliştirilmesi üzerine hazırlanan tezlerin yıllara göre dağılımı

Grafik 1'de görüldüğg̈ gibi yazma becerilerinin geliştirilmesi üzerine yazılan tezlerin en fazla $(f=28) 2019$ ' da hazırlandığı belirlenmiş, bunu on beşer tezin yazıldığ 2017 ve 2018 yılları, on birer tezin yazıldığ 2015,2016 ve 2020 yılları ile 10 tezin yazıldığı 2014 yılı takip etmiştir. Buna göre araştırmada incelenen 132 tezin 101'i $(\% 76,51)$ son yedi yıl içerisinde hazırlanmıştır. Bunun dışında konuyla ilgili olarak 2011'de 7, 2013'te 6, 2006 ve 2012 'te 4, 2007 ve $2010^{\prime}$ da 3, 2005'te 2, 2008 ve 2009'da da 1 çalışmanın gerçekleştirildiği görülmektedir. 


\section{İkinci Araştırma Sorusuna Yönelik Bulgular}

Araştırmanın "Yazma becerilerinin geliştirilmesi üzerine hazırlanan tezlerin öğrenim kademesine göre dağılımı nasıldır?" şeklindeki ikinci sorusuna yönelik bulgular Grafik 2'de gösterilmiştir.

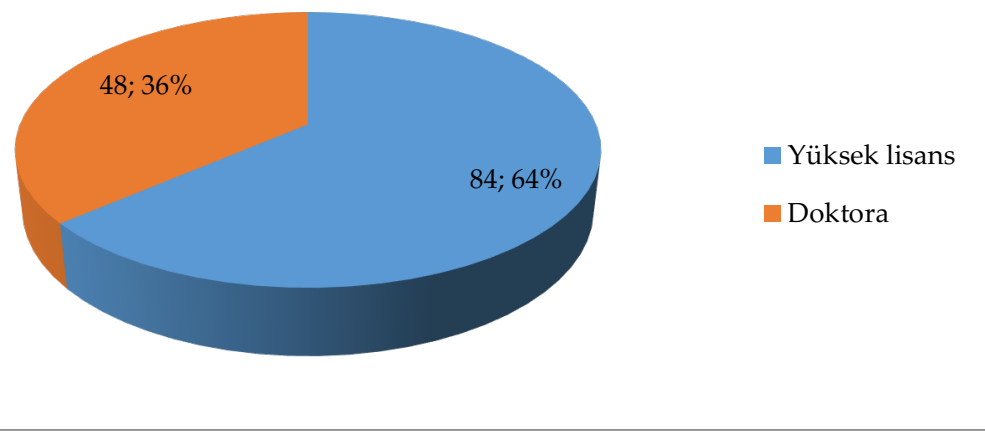

Grafik 2. Yazma becerilerinin geliştirilmesi üzerine hazırlanan tezlerin öğrenim kademesine göre dă̆ılımı

Grafik 2'ye göre yazma becerilerinin geliştirilmesi üzerine yazılan 132 tezin $84^{\prime}$ ü (\%64) yüksek lisans, 48'i (\%36) ise doktora düzeyinde hazırlanan çalışmalardan oluşmaktadır.

\section{Üçüncü Araştırma Sorusuna Yönelik Bulgular}

Araştırmanın "Yazma becerilerinin geliştirilmesi üzerine hazırlanan tezlerin hazırlandıkları üniversitelere göre dağılımı nasıldır?" şeklindeki üçüncü sorusuna yönelik bulgular Tablo 1'de yer almaktadır.

Tablo 1. Yazma becerilerinin geliştirilmesi üzerine hazırlanan tezlerin hazırlandıkları üniversitelere göre dă̆ılımı

\begin{tabular}{llll}
\hline Kurum Adı & YL (f) & DR (f) & Toplam (f) \\
\hline Gazi Üniversitesi & 6 & 15 & 21 \\
Ankara Üniversitesi & 2 & 9 & 11 \\
Hatay Mustafa Kemal Üniversitesi & 6 & 3 & 9 \\
Bolu Abant İzzet Baysal Üniversitesi & 7 & - & 7 \\
Dokuz Eylül Üniversitesi & 4 & 2 & 6 \\
Muğla Sitkı Koçman Üniversitesi & 6 & - & 6 \\
Atatürk Üniversitesi & 1 & 4 & 5 \\
\hline
\end{tabular}




\begin{tabular}{llll}
\hline Kırşehir Ahi Evran Üniversitesi & 4 & - & 4 \\
Anadolu Üniversitesi & 2 & 2 & 4 \\
Çanakkale Onsekiz Mart Üniversitesi & 3 & 1 & 4 \\
Kütahya Dumlupinar Üniversitesi & 4 & - & 4 \\
Gaziantep Üniversitesi & 4 & - & 4 \\
Hacettepe Üniversitesi & 1 & 3 & 4 \\
Kırıkkale Üniversitesi & 4 & - & 4 \\
Frat Üniversitesi & 1 & 2 & 3 \\
Marmara Üniversitesi & 3 & - & 3 \\
Necmettin Erbakan Üniversitesi & 3 & - & 3 \\
Ağrn İbrahim Çeçen Üniversitesi & 2 & - & 2 \\
Akdeniz Üniversitesi & 2 & - & 2 \\
Zonguldak Bülent Ecevit Üniversitesi & 2 & - & 2 \\
Giresun Üniversitesi & 2 & - & 2 \\
İnönü Üniversitesi & 1 & 1 & 2 \\
Ondokuz Mayıs Üniversitesi & 2 & - & 2 \\
Pamukkale Üniversitesi & 1 & 1 & 2 \\
Sakarya Üniversitesi & 1 & 1 & 2 \\
Diğer & 10 & 4 & 14 \\
\hline Toplam & 84 & 48 & 132 \\
\hline
\end{tabular}

Tablo 1'e göre yazma becerilerinin geliştirilmesi üzerine yazılan tezlerin en fazla Gazi Üniversitesi ( $\mathrm{f}=21$ ) ve Ankara Üniversitesi ( $\mathrm{f}=11$ ) bünyesinde hazırlandığı görülmektedir. Bu kurumları Hatay Mustafa Kemal Üniversitesi ( $\mathrm{f}=9$ ), Bolu Abant İzzet Baysal Üniversitesi ( $\mathrm{f}=7$ ), Dokuz Eylül Üniversitesi, Muğla Sıtkı Koçman Üniversitesi ( $\mathrm{f}=6$ ), Atatürk Üniversitesi $(\mathfrak{f}=5)$, Kırşehir Ahi Evran Üniversitesi, Anadolu Üniversitesi, Çanakkale Onsekiz Mart Üniversitesi, Kütahya Dumlupınar Üniversitesi, Gaziantep Üniversitesi, Hacettepe Üniversitesi, Kırıkkale Üniversitesi ( $f=4)$, Furat Üniversitesi, Marmara Üniversitesi, Necmettin Erbakan Üniversitesi ( $\mathrm{f}=3$ ), Ağrı İbrahim Çeçen Üniversitesi, Akdeniz Üniversitesi, Zonguldak Bülent Ecevit Üniversitesi, Giresun Üniversitesi, İnönü Üniversitesi, Ondokuz Mayıs Üniversitesi, Pamukkale Üniversitesi, Sakarya Üniversitesi ( $\mathrm{f}=2$ ) takip etmiştir. Bunların dışında 14 farklı üniversitede de konuyla ilgili birer çalışma gerçekleştirilmiştir. Öğrenim kademesine göre bakıldığında yüksek lisans tezlerinin en fazla Bolu Abant İzzet Baysal Üniversitesi (f=7), Gazi Üniversitesi, Hatay Mustafa Kemal Üniversitesi ve Muğla Sıtkı Koçman Üniversitesinde $(f=6)$, doktora tezlerinin ise Gazi Üniversitesi ( $f=15$ ) ve Ankara Üniversitesinde ( $\mathrm{f}=9$ ) hazırlandığ 1 belirlenmiştir. 


\section{Dördüncü Araştırma Sorusuna Yönelik Bulgular}

Araştırmanın "Yazma becerilerinin geliştirilmesi üzerine hazırlanan tezlerin hazırlandıkları bilim dallarına göre dağılımı nasıldır?" şeklindeki dördüncü soruna yönelik bulgulara Grafik 3'te yer verilmiştir.

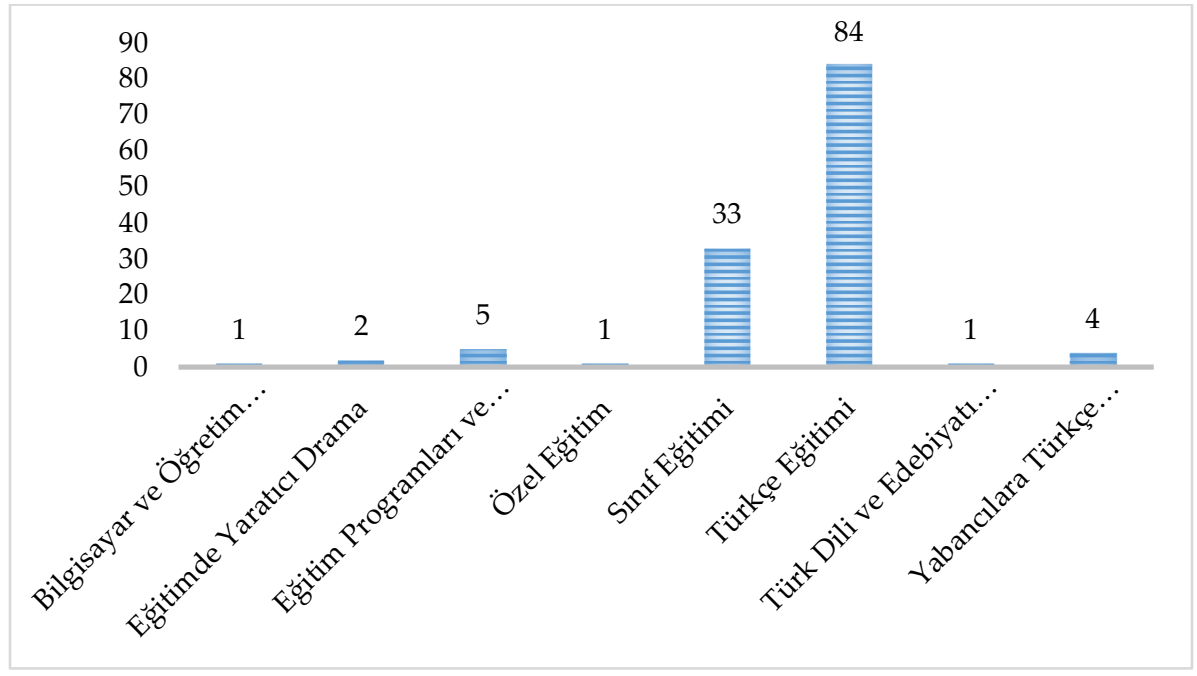

Grafik 3. Yazma becerilerinin geliştirilmesi üzerine hazırlanan tezlerin hazırlandıkları bilim dallarına göre dă̆ılımı

Grafik 3'te görüldüğü üzere yazma becerilerinin geliştirilmesi üzerine hazırlanan tezlerin en fazla Türkçe Eğitimi (f=84) ile Sınıf Eğitimi (\%33) bilim dallarında hazırlandığı tespit edilmiştir. Bunların dışında Eğitim Programları ve Öğretim (f=5), Yabancılara Türkçe Öğretimi (f=4), Eğitimde Yaratıcı Drama (f=2), Bilgisayar ve Öğretim Teknolojileri, Özel Eğitim ile Türk Dili ve Edebiyatı Eğitimi ( $\mathrm{f}=1$ ) bilim dallarında da konuyla ilgili tezlere rastlanmıştır.

\section{Beşinci Araştırma Sorusuna Yönelik Bulgular}

Araştırmanın "Yazma becerilerinin geliştirilmesi üzerine hazırlanan tezlerin danışman unvanlarına göre dağılımı nasıldır?" şeklindeki beşinci sorusuna yönelik bulgular Tablo 2' de gösterilmiştir. 
Tablo 2. Yazma becerilerinin geliştirilmesi üzerine hazırlanan tezlerin danışman unvanlarına göre dă̆ılımı*

\begin{tabular}{lllllll}
\hline Unvan & YL & $\mathbf{\%}$ & DR & $\mathbf{\%}$ & $\mathbf{f}$ & $\mathbf{\%}$ \\
\hline Dr. Öğr. Üyesi/Yrd. Doç. Dr. & 39 & $\% 46$ & 6 & $\% 11$ & 45 & $\% 33$ \\
Doç. Dr. & 38 & $\% 45$ & 16 & $\% 30$ & 54 & $\% 39$ \\
Prof. Dr. & 8 & $\% 9$ & 31 & $\% 59$ & 39 & $\% 28$ \\
\hline Toplam & 85 & & 53 & & 138 & \\
\hline
\end{tabular}

* Tezlerin 6'sında (5 doktora-1 yüksek lisans) çift danışman uygulaması vardır.

Tablo 2'ye göre yazma becerilerinin geliştirilmesi üzerine hazırlanan tezlerde en fazla ( $\mathrm{f}=54 ; \% 39)$ "Doç. Dr." unvanına sahip akademisyenlerin danışmanlık yaptı̆̆ı görülmektedir. "Dr. Öğr. Üyesi/Yrd. Doç. Dr.” unvanlı akademisyenin danışmanlı̆̆ını yürüttüğü tez sayısı 45 (\%33), "Prof. Dr." unvanlı akademisyenin danışmanlığını yürüttüğü tez sayısı ise 39 'dur (\%28). Tezlerin öğrenim kademesine göre bakıldığında yüksek lisans tezlerinde danışmanların daha çok "Dr. Öğr. Üyesi/Yrd. Doç. Dr." ( $\mathrm{f}=39$, \%46) ve "Doç. Dr." ( $\mathrm{f}=38, \% 45)$ unvanına sahip olduğu görülürken doktora tezlerinde ağırlığın "Prof. Dr." (f=31, \%59) unvanlı danışmanlarda olduğu görülmektedir.

\section{Altıncı Araştırma Sorusuna Yönelik Bulgular}

Araştırmanın "Yazma becerilerinin geliştirilmesi üzerine hazırlanan tezlerin çalışma gruplarına göre dağılımı nasıldır?" şeklindeki altıncı sorusuna yönelik bulgular Tablo 3'te yer almaktadır.

Tablo 3. Yazma becerilerinin geliştirilmesi üzerine hazırlanan tezlerin çalışma gruplarına göre dă̆ılımı

\begin{tabular}{|c|c|c|}
\hline Öğrenim Kademesi & $\mathrm{f}$ & $\%$ \\
\hline İlkokul & 25 & $\% 18$ \\
\hline 2. sinif & 2 & \\
\hline 3. sinif & 2 & \\
\hline 4. sinif & 21 & \\
\hline Ortaokul & 78 & $\% 58$ \\
\hline $5 . \operatorname{sinif}$ & 19 & \\
\hline 6. sinif & 23 & \\
\hline 7. sinif & 22 & \\
\hline 8. sinif & 14 & \\
\hline Lisans & 11 & $\% 8$ \\
\hline Öğretmen adayları & 10 & \\
\hline Diğer & 1 & \\
\hline Yabancı Uyruklu Öğrenciler & 20 & $\% 15$ \\
\hline Diğer & 1 & $\% 1$ \\
\hline
\end{tabular}


Tablo 3'e göre yazma becerilerinin geliştirilmesi üzerine hazırlanan tezlerin çalışma grupları büyük oranda ( $\mathrm{f}=78, \% 58)$ ortaokul öğrencilerinden oluşmuştur. Sınıf düzeyine göre bakıldığında aralarında çok büyük bir fark olmamakla beraber 6 ve 7. sınıf öğrencilerine çalışma gruplarında daha çok yer verildiği, buna karşın 8. sınıflarla daha az çalışıldığ görülmektedir. İlkokul öğrencileri (f=25, \%18), çalışma gruplarında ortaokul öğrencilerinden sonra en fazla yer verilenler olurken bu öğrenim kademesinde gerçekleştirilen araştırmalarda daha çok 4. sınıflarla çalışılmıştır. Bunların dişında yabancı uyruklu öğrenciler ( $\mathrm{f}=20$, \%15) ile lisans öğrencilerinin $(\mathrm{f}=11, \% 8)$ yazma becerilerini geliştirmeye dönük araştırmalar da mevcuttur.

\section{Yedinci Araştırma Sorusuna Yönelik Bulgular}

Araştırmanın "Yazma becerilerinin geliştirilmesi üzerine hazırlanan tezlerin bağımsız değişkenlere göre dağılımı nasıldır?" şeklindeki yedinci sorusuna yönelik bulgulara Tablo 4'te yer verilmiştir.

Tablo 4. Yazma becerilerinin geliştirilmesi üzerine hazırlanan tezlerin bağımsız değişkenlere göre dă̆ılımı

\begin{tabular}{|c|c|c|}
\hline Tema & $\mathbf{f}$ & Bağımsız Değişkenler \\
\hline Yazma Yöntem Teknikleri & 43 & $\begin{array}{l}\text { Yaratıcı yazma ( }(\mathrm{f}=12) \text {, planlı yazma }(\mathrm{f}=7) \text {, analitik yazma }(\mathrm{f}=5) \text {, süreç } \\
\text { temelli yazma }(\mathrm{f}=5) \text {, yazma stratejileri }(\mathrm{f}=2) \text {, kelime ağı oluşturma } \\
(\mathrm{f}=2) \text {, grup olarak yazma, özet çıarma, eleştirel yazma, seçerek } \\
\text { yazma, kümeleme tekniği, kuantum yazma, cümle piramidi, kurgu } \\
\text { merdiveni, dört kare yazma, kafiye tablosu }(\mathrm{f}=1)\end{array}$ \\
\hline $\begin{array}{l}\text { Öğretim Yöntem Teknik- } \\
\text { leri }\end{array}$ & 27 & $\begin{array}{l}\text { İşbirlikli öğrenme (f=6), 5E öğrenme modeli }(\mathrm{f}=2) \text {, yansıtıcı düşünme } \\
(\mathrm{f}=2) \text {, zihin haritası tekniği }(\mathrm{f}=2) \text {, ters yüz öğrenme }(\mathrm{f}=2) \text { örnek olay, } \\
\text { çoklu zekâ, argümantasyon, öğrenme stratejileri, zihinsel tasarım mo- } \\
\text { delleri, çağrışım tekniği, etkin öğrenme, bütünleştirilmiş öğrenme- } \\
\text { öğretme, basamaklı öğretim, karma öğretim, iletişimsel yaklaşım, } \\
\text { proje tabanlı öğrenme, bilişsel süreç modeli }(\mathrm{f}=1)\end{array}$ \\
\hline Metin/Görsel Kullanımı & 15 & $\begin{array}{l}\text { Dijital öykü }(\mathrm{f}=5) \text {, öykü }(\mathrm{f}=2) \text {, karikatür }(\mathrm{f}=2) \text {, görseller }(\mathrm{f}=2) \text {, çocuk ki- } \\
\text { tapları, metinler arası okuma, şiir, masal, }(\mathrm{f}=1)\end{array}$ \\
\hline $\begin{array}{l}\text { Yazı Türleri/Unsurlarının } \\
\text { Öğretimi }\end{array}$ & 12 & $\begin{array}{l}\text { Tartışmacı metin (f=3), paragraf yazma (f=2), öykü, küçürek öykü, } \\
\text { şiir, metin yapısı, sentez metin, anlatım biçimleri, araştırmacı yazma } \\
(\mathrm{f}=1)\end{array}$ \\
\hline Oyun Temelli Öğrenme & 11 & Yaratıcı drama (f=7), eğitsel oyunlar ( $\mathrm{f}=2)$, dijital uygulamalar $(\mathrm{f}=2)$ \\
\hline Değerlendirme & 10 & $\begin{array}{l}\text { Geri bildirim (f=5), öz düzenlemeli strateji geliştirme ( } \mathrm{f}=3) \text {, çoklu de- } \\
\text { ğerlendirme, performans değerlendirme }(\mathrm{f}=1)\end{array}$ \\
\hline Materyal & 6 & $\begin{array}{l}\text { Ders günlüğü, otantik materyaller, dinleme materyalleri, yazma geli- } \\
\text { şim dosyası, ağ günlükleri, yazma etkinlikleri }(\mathrm{f}=1)\end{array}$ \\
\hline
\end{tabular}




\begin{tabular}{lll}
\hline Ortam & 5 & $\begin{array}{l}\text { Çok uyaranlı eğitim ortamları }(\mathrm{f}=2) \text {, yazma atölyesi, yapılandırılmıs } \\
\text { eğitim ortamları, müzede eğitim }(\mathrm{f}=1)\end{array}$ \\
\hline Ders & 4 & $\begin{array}{l}\text { Yazma eğitimi }(\mathrm{f}=2), \text { otantik yazma, yazarlık ve yazma becerileri } \\
\text { dersi }(\mathrm{f}=1)\end{array}$ \\
\hline
\end{tabular}

Tablo 4'te görüldüğü gibi yazma becerilerinin geliştirilmesi üzerine yarı deneysel desen kullanılarak hazırlanan tezlerin bağımsız değişkenleri dokuz temada toplanmiş, bu temalardan araştırmalarda en fazla yazma yöntem teknikleri $(\mathrm{f}=43)$ ile öğretim yöntem teknikleri $(\mathrm{f}=27)$ bağımsız değişken olarak kullanılmıştır. Bağımsız değişkenler tek tek değerlendirildiğinde ise araştırmalarda en çok yaratıcı yazma $(\mathrm{f}=12)$, planlı yazma $(\mathrm{f}=7)$, yaratıcı drama $(\mathrm{f}=7)$, işbirlikli öğrenme $(\mathrm{f}=6)$, analitik yazma $(\mathrm{f}=5)$, süreç temelli yazma ( $f=5)$, dijital öykü kullanımı $(\mathrm{f}=5)$ ve geri bildirimin ( $\mathrm{f}=5)$ öğrencilerin yazma becerilerine etkisi incelenmiştir.

\section{Sekizinci Araştırma Sorusuna Yönelik Bulgular}

Araştırmanın "Yazma becerilerinin geliştirilmesi üzerine hazırlanan tezlerin yarı deneysel yöntemlere göre dağılımı nasıldır?" şeklindeki sekizinci sorusuna yönelik bulgular Tablo 5'te gösterilmiştir.

Tablo 5. Yazma becerilerinin geliştirilmesi üzerine hazırlanan tezlerin yar deneysel yöntemlere göre dă̆ılımı

\begin{tabular}{lllll}
\hline Yöntem & YL & DR & Toplam & f \\
\hline Ön test- son test kontrol gruplu desen & 73 & 46 & 119 & $\% 90$ \\
Ön test-son test tek gruplu desen & 11 & 2 & 13 & $\% 10$ \\
Toplam & 84 & 48 & 132 & $\% 100$ \\
\hline
\end{tabular}

Tablo 5'te görüldügü gibi yazma becerilerinin geliştirilmesi üzerine hazırlanan yarı deneysel çalışmaların 119 tanesinde (\%90) ön test-son test kontrol gruplu desen tercih edilirken 13 tanesinde (\%10) ön test-son test tek gruplu desen kullanılmıştır. Tez türüne göre bakıldığında ön test-son test kontrol gruplu desenin yüksek lisans tezlerinin 73'ünde (\%87), doktora tezlerinin ise 46 'sında (\%96) kullanıldığı görülmektedir. 


\section{Dokuzuncu Araştırma Sorusuna Yönelik Bulgular}

Araştırmanın "Yazma becerilerinin geliştirilmesi üzerine hazırlanan tezlerin deney grubundaki katılımcı sayısına göre dağılımı nasıldır?" şeklindeki dokuzuncu sorusuna yönelik bulgular Grafik 4'te yer almaktadır.

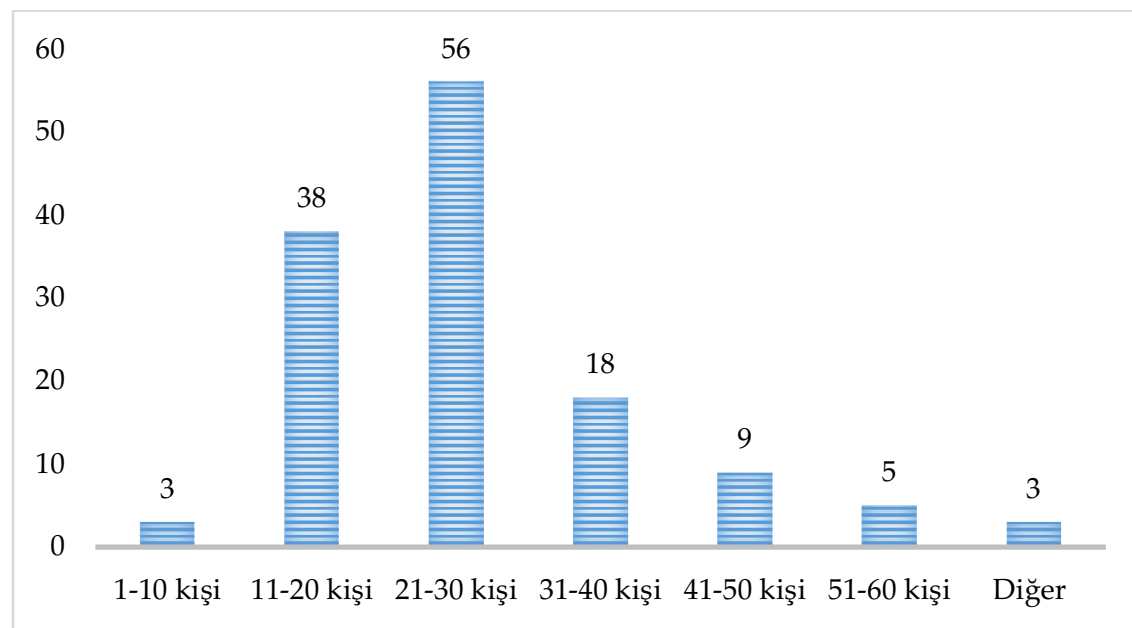

Grafik 4. Yazma becerilerinin geliştirilmesi üzerine hazırlanan tezlerin deney grubundaki katılımcı sayısına göre dağılımı

Grafik 4'e göre yazma becerilerinin geliştirilmesi üzerine hazırlanan tezlerde en fazla 21-30 ( $\mathrm{f}=56), 11-20(\mathrm{f}=38)$ ve 31-40 ( $\mathrm{f}=18)$ kişilik gruplarla çalışıldığı görülmektedir. Buna göre toplam çalışmaların \%85'inde 11-40 kişilik grupların araştırmaların örneklemi olduğu söylenebilir. Ayrıca 9 araştırmada 41-50 kişi, 5 araştırmada 51-60 kişi ve üçer araştırmada da 110 kişi ile 61 ve üzeri sayıdaki kişilerin çalışma gruplarını oluşturduğu belirlenmiştir.

\section{Onuncu Araştırma Sorusuna Yönelik Bulgular}

Araştırmanın "Yazma becerilerinin geliştirilmesi üzerine hazırlanan tezlerin uygulama sürelerine göre dağılımı nasıldır?" şeklindeki onuncu sorusuna yönelik bulgulara Grafik 5'te yer verilmiştir. 


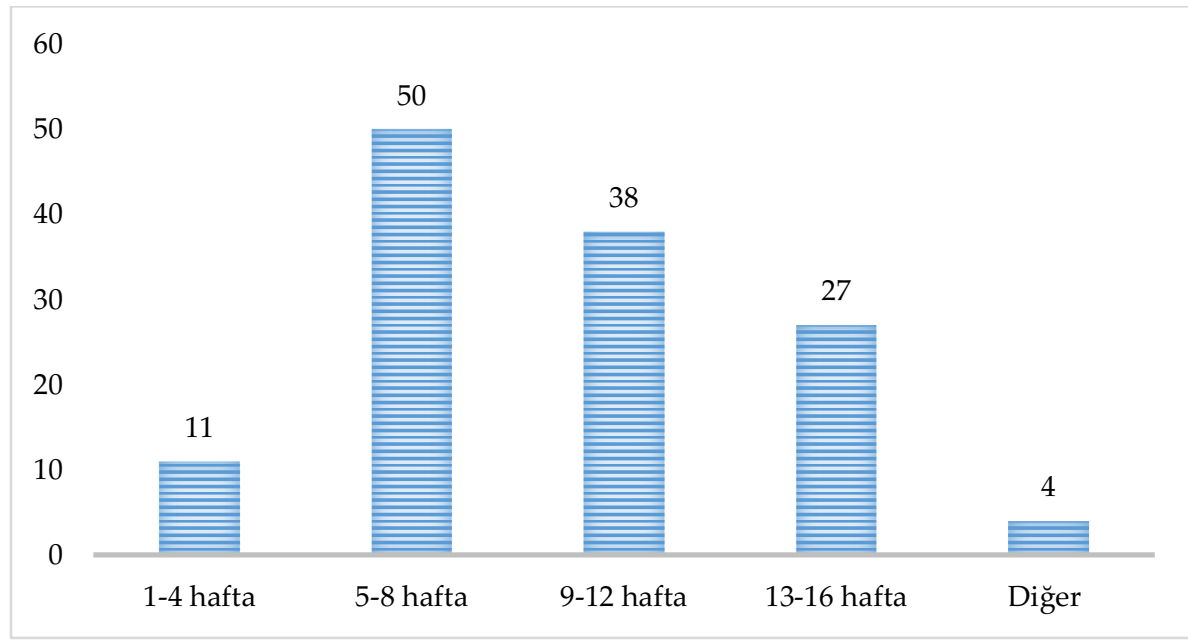

Grafik 5. Yazma becerilerinin geliştirilmesi üzerine hazırlanan tezlerin uygulama sürelerine göre dă̆ılımı

Grafik 5'te görüldüğü üzere yazma becerilerinin geliştirilmesi için yapılan yarı deneysel çalışmaların uygulama süreleri en fazla 5-8 hafta $(\mathrm{f}=50), 9-12$ hafta $(\mathrm{f}=38)$ ve 13-16 hafta $(\mathrm{f}=11)$ şeklinde karşımıza çıkmaktadir. Bununla beraber uygulama aşaması $1-4$ hafta $(\mathrm{f}=11)$ ve 16 haftadan daha fazla $(\mathrm{f}=4)$ olan araştırmalar da mevcuttur.

\section{Tartışma ve Sonuç}

Öğrencilerin yazılı anlatım becerilerinin geliştirilmesi, Türkçe öğretiminin en önemli hedef ve görevlerindendir. Bunun için öğrencilere aktarılacak teorik bilgilerden ziyade uygulamaya dönük çalışmalara ağırlık verilmesine çalışılmalıdır. Bu araştırmada yazılı anlatım becerilerinin geliştirilmesinde yarı deneysel modeller kullanılarak hazırlanmış tezlerin çeşitli açılardan incelenmesi amaçlanmış, ulaşılan sonuçlara ve bu sonuçların alanyazındaki araştırmalarla ilgisine bu bölümde yer verilmiştir.

Yazma becerilerinin geliştirilmesi üzerine hazırlanan tezlerin yıllara göre dağılımına bakıldığında 2014'ten sonra belirgin bir artışın olduğu söylenebilir. Nitekim 2014-2020 yılları arasında hazırlanan tezlerin bütün çalışmalar içerisindeki oranı \%76,51 olarak gerçekleşmiştir. Konuyla ilgili en fazla çalışmanın olduğu yıl ise 2019'dur ( $\mathrm{f}=28)$. Bunu 2017, 2018 (f=15), 
2015, 2016 ve 2020 yılları ( $\mathrm{f}=11$ ) yılları takip etmektedir. Tez savunmaları sonrasında araştırmaların sisteme yüklenmesi belli bir zaman aldığından ve araştırma verileri 2020 yılı sonunda toplandığından özellikle bu yıl içerisindeki tez sayısının ilerleyen süreçte daha da artacağı düşünülmektedir. Bu sonuçlara göre son yıllarda yazma becerisinin geliştirilmesi amacıyla yarı deneysel yöntemin kullanıldığ 1 çalışmaların önem kazandığ 1 söylenebilir. Son dönemde yazma becerisiyle ilgili yapılan araştırmaların (Karagöz ve Şeref, 2020; Temizkan ve Erdevir, 2020) sonuçları da yayın sayılarının gerek makale gerek tez olarak giderek arttığını göstermekte ve bu yargıyı desteklemektedir.

Yazma becerilerinin geliştirilmesi üzerine hazırlanan tezlerde yüksek lisans tezlerinin doktora tezlerine oranla daha fazla olduğu görülmektedir. Konuyla ilgili araştırmaların ( $f=132) \% 64$ 'ü yüksek lisans düzeyinde hazırlanırken \%36'sı doktora düzeyinde hazırlanmıştır. Bu sonuç, Türkçe eğitimiyle ilgili araştırmaların (Alver ve Taştemir, 2017; Ceran, Aydın ve Onarıcıoğlu, 2018; Coşkun, Özçakmak ve Balc1, 2012; Elbir ve Bağcl, 2013; Göksu, 2016; Kardaş, Çetinkaya ve Kara, 2018; Özçakmak, 2017; Özdemir, 2018; Yağmur-Şahin, Kana ve Varışoğlu, 2013; Yılmaz ve Kaya, 2020) sonuçlarıyla paralellik arz etmektedir. Türkçe eğitiminde yüksek lisans programlarının ve öğrenci sayılarının doktora programlarına ve öğrenci sayılarına oranla daha fazla olmasının bu sonuçta etkili olduğu tahmin edilmektedir.

Tezlerin üniversitelere göre dağılımı incelendiğinde 132 çalışmanın 39 farklı kurum bünyesinde hazırlandığı sonucuna ulaşılmıştır. Gazi Üniversitesi ( $\mathrm{f}=21)$ ile Ankara Üniversitesi $(\mathrm{f}=11)$ en fazla tez çalışmasının gerçekleştirildiği kurumlar olarak öne çıkmıştır. Ayrıca bu üniversiteler öğrenim kademesine göre bakıldığında doktora tezlerinin yoğun olarak hazırlandığg kurumlar olmuştur. Zira araştırmada değerlendirmeye alınan 48 doktora tezinin \%50'sinin ( $\mathrm{f}=24$ ) bu iki üniversite bünyesinde hazırlandığı tespit edilmiştir. Alanyazındaki çalışmalara bakıldığında Gazi Üniversitesi, Türkçe eğitimi alanındaki lisansüstü tezlerin (Coşkun, Özçakmak ve Balcı, 2012; Özçakmak, 2017), doktora tezlerinin (Boyacı ve Demirkol, 2018), yazma eğitimi (Coşkun, Balcı ve Özçakmak, 2013; Elbir ve Yıldız, 2012), dinleme eğitimi (Doğan ve Özçakmak, 2014), okuma eğitimi (Ceran, Aydın ve Onarıcıoğlu, 2018; Elbir ve Bağcl, 2013; Özdemir, 2018), konuşma eğitimi (Alver ve Taştemir, 2017) ve dil bilgisi öğretimiyle ilgili lisansüstü 
tezler (Göçer ve Arslan, 2018) ile yabancılara Türkçe öğretimiyle ilgili tezlerin (Çelebi, Ergül, Usta ve Mutlu, 2019; Türkben, 2018) en fazla hazırlandığı üniversite olarak dikkat çekmektedir. Bu sonucun ortaya çıkmasında üniversitenin kurumsallaşmasının, lisansüstü yapılanmaya erken başlamasının ve akademik kadro yeterliliğinin önemli rolü olduğunu düşünülmektedir.

Yazma becerilerinin geliştirilmesi üzerine hazırlanan tezlerin bilim dallarına göre dağılımına bakıldığında sekiz farklı bilim dalında bu çalışmaların gerçekleştirildiği belirlenmiştir. Türkçe Eğitimi $(\mathfrak{f}=84, \% 63,63)$ ile Sınıf Eğitimi ( $\mathrm{f}=33, \% 25)$, konuyla ilgili araştırmaların en fazla yapıldığ bilim dalları olarak öne çıkmıştır. Özçakmak'ın (2017) araştırmasında da Türkçe eğitimi konusunda yapılan tezlerin \%54'ünün Türkçe eğitimiyle ilgili ana bilim dallarında hazırlandığı şeklinde bir bulguya ulaşılmıştır. Yazma becerisinin Türkçe eğitimi bilim dalının önemli çalışmaları konuları arasında olmasının yanında araştırmaların hedef kitlelerinin daha çok ortaokul düzeyindeki öğrenciler olmasının da tez çalışmalarında ilgili bilim dalını öne çıkardığı ifade edilebilir.

Tezleri yürüten danışmanların unvanlarına göre dağılım incelendiğinde ilk sırayı "Doç. Dr." (\%39), ikinci sırayı “Dr. Öğr. Üyesi/Yrd. Doç. Dr." (\%33) ve son sırayı da "Prof. Dr." (\%28) unvanlı danışmanların aldığı belirlenmiştir. Öğrenim kademesine göre bakıldığında yüksek lisans tez danışmanlarının daha çok “Dr. Öğr. Üyesi/Yrd. Doç. Dr.” (\%46) ve “Doç. Dr." (\%45) unvanına sahip akademisyenler olduğu, buna karşın doktora tez danışmanlarında "Prof. Dr." (\%59) unvanına sahip akademisyenlerin belirgin şekilde öne çıtığı görülmüştür. Bu sonuç, Türkçe eğitimi alanındaki doktora tezlerinin danışman unvanlarını tespit eden Boyacı ve Demirkol'un (2018) araştırma sonuçlarıyla benzerlik göstermektedir. İlgili araştırmada alandaki doktora tezlerinin \%63,5'inin "Prof. Dr." unvanlı danışmanlar tarafından yürütüldüğü ortaya çıkmıştır. Okuma eğitimiyle ilgili tezleri inceleyen bir diğer araştırmada (Elbir ve Bağc1, 2013) yüksek lisans tezlerinin \%63'ünün "Yrd. Doç. Dr.", doktora tezlerinin ise \%78' inin "Prof. Dr." unvanına sahip danışmanlarca yürütüldügü tespit edilmiştir. Ülkemizde 2005-2015 yılları arasında ilk okuma yazma alanında yapılan tezleri değerlendiren Kadıŏglu-Ateş ve Kadıŏ̆lu'nun (2017) çalışmasında da yüksek lisans tezlerinin \%70' ine "Yrd. Doç. Dr." unvanlı akademisyenler danışmanlık yaparken doktora tezlerinin \%59'una "Prof. Dr." unvanlı 
akademisyenlerin danışmanlık yaptığı belirlenmiştir. Bunda doktora tezlerinin danışmanlık dağılımlarında "Prof. Dr." unvanlı akademisyenlerin daha çok tercih edilmesinin/öncelikli olmasının etkisi olabileceği düşünülmektedir.

Ortaokul öğrencileri (\%58) ile ilkokul öğrencileri (\%18), yazma becerilerinin geliştirilmesi üzerine hazırlanan tezlerin çalışma gruplarına en çok dâhil edilen öğrenciler olmuştur. Bunu yabancı uyruklu öğrenciler (\%15) ve lisans öğrencileri (\%8) izlemiştir. Tok ve Potur'un (2015) yazma eğitimi araştırmalarındaki eğilimleri belirledikleri çalışmada da ortaokul öğrencileri hedef kitlelerde ilk sırayı (f=67) almıştır. Türkçe eğitimi (Özçakmak, 2017; Coşkun, Balcı ve Özçakmak, 2013; Yağmur-Şahin, Kana ve Var1şoğlu, 2013), okuma becerisi (Akaydın ve Çeçen, 2015; Ceran, Aydın ve Onarıcıŏlu, 2018; Özdemir, 2018), konuşma becerisi (Alver ve Taştemir, 2017; Potur ve Yıldız, 2016), dinleme becerisi (Doğan ve Özçakmak, 2014; Kardaş, Çetinkaya ve Kaya, 2018) ve dil bilgisiyle (Göçer ve Arslan, 2018) ilgili çalışmaları ele alan çeşitli araştırmalarda da ortaokul öğrencilerinin örneklem gruplarında ilk sırayı aldıkları tespit edilmiştir. Türkçe eğitimi ana bilim dallarının ortaokulda görev yapacak öğretmenleri yetiştirmesinin, araştırmaların hedef kitlesinin çoğunlukla ortaokul öğrencileri olmasinda önemli rol oynadığı söylenebilir.

Yazma becerilerinin geliştirilmesi üzerine hazırlanan tezlerin bağımsız değişkenlere göre dağılımı incelendiğinde yazma yöntem teknikleri ( $f=43$ ) ile öğretim yöntem tekniklerinin ( $\mathrm{f}=27$ ) araştırmacılar tarafından daha çok çalışıldığı söylenebilir. Bu sonuç, Tok ve Potur'un (2015) yazma eğitimi çalışmalarının daha çok yöntemlerin etkililiği üzerinde yoğunlaştığını gösteren araştırmalarının sonuçlarıyla benzerlik göstermektedir. Coşkun, Özçakmak ve Balcı (2012) ile Özçakmak (2017) tarafından gerçekleştirilen araştırmalarda da Türkçe eğitimiyle ilgili lisansüstü tezlerde öğretim strateji, yöntem ve tekniklerinin en fazla çalışılan konular olduğu ortaya konulmuştur. Bununla beraber Ceran, Aydın ve Onarıcıŏlu'nun (2018) okuma becerisiyle ilgili tezleri, Alver ve Taştemir'in (2017) konuşma becerisiyle ilgili tezleri, Doğan ve Özçakmak' in (2014) dinleme becerisiyle ilgili tezleri inceledikleri çalışmalarda da öğretim strateji, yöntem ve tekniklerinin en çok çalışılan konular olduğu belirtilmiştir. Yarı deneysel çalışma- 
larda genelde bir model, yöntem ve tekniğin bağımlı değişkenler üzerindeki etkisi araştırıldığından yazma becerilerinin geliştirilmesinde de araştırmacıların tercihlerini bu yönde kullandıkları görülmektedir.

Yazma becerilerinin geliştirilmesi üzerine hazırlanan ve yarı deneysel modelin tercih edildiği tezlerin \%90'inda ön test-son test kontrol gruplu desene yer verilmiş, ön test-son test tek gruplu desenin oranı $\% 10^{\prime}$ da kalmıştır. Yazılı anlatım becerisiyle ilgili yüksek lisans tezlerini inceleyen Temizkan ve Erdevir'in (2020) araştırmasında da ön test-son test kontrol gruplu desenin tarama modeliyle birlikte çalışmalarda en fazla tercih edilen yöntem olduğu belirlenmiştir. Yılmaz ve Kaya'nın (2020) ilkokul düzeyinde Türkçe eğitimiyle ilgili tezleri ele aldıkları araştırmada da yarı deneysel çalışmalarda çoğunlukla kontrol gruplu desenin kullanıldığı tespit edilmiştir. Gürbüz ve Şahin'e (2017) göre tek grup ön test-son test deseninde kontrol grubu olmaması nedeniyle testler arasındaki farklılığın verilen eğitimden kaynaklandığını söylemek güçtür. Tek grubun bu dezavantajından dolayı araştırmacıların çoğunlukla uygulamalarında kontrol gruplarına yer verme eğilimi içinde oldukları görülmektedir.

Yazma becerilerinin geliştirilmesi üzerine hazırlanan tezlerin çalışma gruplarındaki kişi sayısına bakıldığında en fazla 21-30 ( $\mathrm{f}=56), 11-20$ ( $\mathrm{f}=38$ ) ve 31-40 kişilik ( $\mathrm{f}=18$ ) gruplarla çalışıldığı ortaya çıkmıştır. Buna göre araştırmaların \%85'inde çalışma gruplarında 11-40 kişiye yer verilmiştir. Türkben'in (2018) ve Baki'nin (2019) araştırmalarında yabancı dil olarak Türkçe öğretimi alanındaki tezlerde en fazla 11-30 kişilik örneklem gruplarıyla çalışıldığı şeklinde bulgu, bu sonuçla benzerdir. Ayrıca yarı deneysel desenli çalışmaların uygulamaya dayalı ve sınıf mevcutlarıyla sınırlı olmasından dolayı araştırmalara dâhil edilen öğrenci sayılarının ideal ve yeterli olduğu söylenebilir.

Yazma becerilerinin geliştirilmesi üzerine hazırlanan tezlerin uygulama süreleri incelendiğinde en fazla 5-8 hafta $(f=50), 9-12$ hafta $(f=38)$ ve 13-16 haftalık ( $\mathrm{f}=27)$ çalışmaların gerçekleştirildiği görülmektedir. Bu sonuç Gülen-Canlı ve Tepeli (2019) tarafından gerçekleştirilen ve Türkçe eğitiminde eylem araştırması modeliyle yapılmış çalışmaları ele alan araştırmanın sonuçlarıyla benzerlik göstermektedir. Söz konusu çalışmada da eylem araştırması kullanılan çalışmaların en fazla 5-8 hafta (\%20,9), 9-12 hafta $(\% 12,9)$ ve $13-16$ haftalık $(\% 11,2)$ süreler içerisinde uygulandığı tespit edilmiştir. Araştırmaların uygulama sürelerinde farklılıklar olmasında 
araştırmacıların tercihi, çalışmaların içeriği, izin süreleri vb. faktörlerin etkili olduğu düşünülmektedir.

Yazma becerisi, diğer dil becerilerinde olduğu gibi tedricen gelişen ve uygulamalarla desteklenmesi gereken bir beceridir. Bu sebeple yazma eğitimi çalışmalarının amacı öğrencilere yalnızca teorik bilgilerin aktarılması değil, bu bilgilerin aynı zamanda çeşitli etkinliklerle pratiğe yansıtılması/dökülmesi olmalıdır. Bundan dolayı öğrencilerin yazma becerilerinin geliştirilmesinde uygulamalı çalışmaların son derece önemli bir yeri vardır. Bu araştırmada yarı deneysel desenler kullanılarak çeşitli öğrenim kademelerindeki öğrencilerin yazma becerilerinin geliştirilmesini hedefleyen lisansüstü tezler incelenmiş, böylelikle konuyla ilgili alanyazındaki durumun ortaya konulmasına çalışılmıştır. 


\title{
EXTENDED ABSTRACT
}

\section{A Study on Theses Written on Improving Writing Skills: Quasi-Experimental Studies \\ *}

\author{
Ömer Kemiksiz \\ Bartın University
}

Mostly acquired through a natural process and learned together with reading skill after a certain period of education with listening and speaking (Zorbaz, 2014), and accepted as the last ring of four basic language skills (Demirel, 2000), writing skill is a language skill required to meet the daily needs of individuals, to continue their education, to be successful in their lives, to become people who understand people and are understood by people by increasing their ability to understand and express (Arıc1 \& Ungan, 2015). The importance of writing skill was also mentioned in the Turkish Course Curriculum (MEB, 2019), and the followings were mentioned among the aims of the program: "development of listening/watching, speaking, reading and writing skills" of students, "ensuring that they use Turkish in a conscious, correct and careful manner in accordance with the rules of speaking and writing," "ensuring they acquire the love and habit of reading" and "enabling them to express their feelings and thoughts and their opinions or thesis on a subject in oral and written form effectively and clearly." Accordingly, it is one of the primary goals of Turkish education for all individuals to reach a level that they can express themselves in written form in a good, effective and correct manner throughout their education life.

This study, aiming to analyze various aspects of postgraduate thesis studies carried out by using quasi-experimental models in order to improve writing skills, was conducted in qualitative research design. The data of the study, in which document analysis was used as data collection technique, was analyzed by using content analysis technique. Criterion sampling, one of the purposeful sampling types, was preferred in sample selection. The sample of the study consists of master's and doctoral theses $(\mathrm{f}=132)$ using quasi-experimental design to develop writing skills and carried out between 2005 and 2020. Theses were accessed via YÖK Thesis 
Center. These theses were analyzed in terms of "the year of publication," "level of education," "the university where they were written," "the field in which they were written," "title of supervisor," "study groups," "independent variables," "method of study," "number of participants" and "duration of application".

According to the findings of the study, it was determined that 101 (76.51\%) of 132 theses related to the subject were prepared in the last seven years and the highest number of theses were written in 2019 ( $\mathrm{f}=28)$. In terms of the level of education, $64 \%$ of the theses consist of studies prepared at the master's level and $36 \%$ at the doctoral level. Theses were prepared in 39 different institutions, and Gazi University ( $\mathrm{f}=21)$ and Ankara University ( $\mathrm{f}=11$ ) were the institutions with the highest number of thesis studies. $50 \%$ of the doctoral theses were prepared in these two universities. While it is observed that theses were mostly prepared in the fields of Turkish Education (63.63\%) and Classroom Education (25\%), it was identified that in terms of the title of supervisors, the title of "Dr." (39\%) took the first rank, "Assoc. Prof. Dr." (33\%) took the second rank, and "Prof. Dr." $(28 \%)$ took the third rank. It was identified that in terms of the level of education, scholars with titles of "Dr." (46\%) and "Assoc. Prof. Dr." $(45 \%)$ came to the forefront for master's theses, and scholars with the title of "Prof. Dr." (59\%) came to the forefront for doctoral theses. In the sample groups of the studies, secondary school students were preferred more $(58 \%)$, and it was revealed that the most used independent variables were writing methods/techniques $(\mathrm{f}=43)$ and teaching methods/techniques $(\mathrm{f}=27)$. Pretest-posttest control group designs were used frequently $(90 \%)$ in the studies; groups consisting of 11-40 people were generally studied in the study groups and the applications of the studies mostly took 5-8 weeks $(\mathrm{f}=50)$ and $9-12$ weeks $(\mathrm{f}=38)$.

The findings acquired as a result of the research are similar to the results of various studies in the field of Turkish education. In the relevant research, it was identified that studies on writing skill have increased in recent years (Karagöz and Şeref, 2020; Temizkan and Erdevir, 2020), that theses are mostly at the level of master's degree (Yağmur-Şahin, Kana and Varışoğlu, 2013), that the highest number of theses were written at Gazi University and in the field of Turkish education (Özçakmak, 2017), that 
supervisors in doctoral theses generally have the title of "Prof. Dr." (Boyacı and Demirkol, 2018), that secondary school students were included in the study groups more, and that the effect of writing methods/techniques was generally analyzed in the studies (Tok and Potur, 2015).

\section{Kaynakça / References}

Adalı, O. (2016). Anlamak ve anlatmak. (5. Baskı). İstanbul: Pan.

Akaydın, Ş. ve Çeçen, M. A. (2015). Okuma becerisiyle ilgili makaleler üzerine bir içerik analizi. Eğitim ve Bilim, 40(178), 183-198.

Aktaş, Ş. ve Gündüz, O. (2004). Yazılı ve sözlü anlatım. (5. Baskı). Ankara: Akçă̆.

Akyol, H. (2006). Türkçe ögretim yöntemleri. Ankara: Kök.

Alodwan, T. A. and Ibnian, S. S. K. (2014). The effect of using the process approach to writing on developing university students' essay writing skills in EFL. Review of Arts and Humanities, 3(2), 139-155.

Alver, M. ve Taştemir, L. (2017). Konuşma becerisi üzerine yapılan lisansüstü tezlerin incelenmesi. International Journal of Languages' Education and Teaching, 5(3), 451-462. DOI: $\underline{\text { 10.18298/ijlet.2041 }}$

Arı, G., Yaşar, M. S. ve İstanbullu, E. (2020). Türkçe öğretmeni adaylarıyla ilgili yayımlanan makalelerin incelenmesi (2014-2018). Ana Dili Eğitimi Dergisi, 8(2), 487-508.

Arıcı, A. F. ve Ungan, S. (2015). Yazılı anlatım el kitabı. (3. Baskı). Ankara Pegem.

Baki, Y. (2019). Yabancılara Türkçe öğretimi alanındaki araştırma eğilimleri. International Journal of Language Academy, 7(3), 22-41. DOI:10.29228/ijla.25829

Boyacı, S. ve Demirkol, S. (2018). Türkçe eğitimi alanında yapılan doktora tezlerinin incelenmesi. Ana Dili Eğitimi Dergisi, 6(2), 512-531.

Bozkurt, B. Ü. ve Uzun, N. E. (2015). Türkçenin eğitimi-öğretimine ilişkin bir alanyazını değerlendirmesi: Uluslararası bilimsel toplantılarda eğilimler/yönelimler. Dil Ĕ̆itimi ve Araştırmaları Dergisi, 1(2), 1-15.

Büyüköztürk, Ş., Kılıç-Çakmak, E., Akgün, Ö. E., Karadeniz, Ş. ve Demirel, F. (2020). Ĕ̆itimde bilimsel araştırma yöntemleri. (28. Baskı). Ankara: Pegem.

Ceran, D., Aydın, M. ve Onarıcıoğlu, A. S. (2018). Okuma eğitimi üzerine yapılan tezlerde eğilimler: bir içerik analizi çalışması. Ahi Evran Üniversitesi Kırşehir Eğitim Fakültesi Dergisi, 19(3), 2377-2392. 
Coşkun, E. (2014). Yazma eğitimi. A. Kırkkılıç ve H. Akyol (Ed.), İlköğretimde Türkçe öğretimi içinde, (4. Baskı), (s.49-91). Ankara: Pegem.

Coşkun, E., Balcı, A. ve Özçakmak, H. (2013). Trends in writing education: An analysis of postgraduate theses written in Turkey. Procedia-Social and Behavioral Sciences, 93, 1526-1530.

Coşkun, E., Özçakmak, H. ve Balcı, A. (2012). Türkçe eğitiminde eğilimler: 1981-2010 yılları arasında yapılan tezler üzerine bir meta-analiz çalışması. E. Yılmaz, M. Gedizli, E. Özcan ve Y. Koçmar (Ed.), Türkçenin eğitimi-öğretimi üzerine çalışmalar içinde, (1. Bask1), (s.204-212). Ankara: Pegem.

Çelebi, C., Ergül, E., Usta, B. ve Mutlu. M. (2019). Türkiye'de yabancllara Türkçe öğretimi alanında hazırlanmış lisansüstü tezler üzerine bir meta-analiz çalışması. Temel Ĕ̆gitim Dergisi, 1(3), 39-52.

Demirel, Ö. (2000). Türkçe öğretimi. (2. Bask1). Ankara: Pegem.

Dilidüzgün, Ş. (2020). Süreç ve tür odaklı okuma ve yazma eğitimi. (1. Bask1). Ankara: Anı.

Doğan, Y. ve Özçakmak, H. (2014). Dinleme becerisinin eğitimi üzerine yap1lan lisansüstü tezlerin değerlendirilmesi. Ana Dili Ĕ̆itimi Dergisi, 2(2), 90-99.

Durga, S. S. and Rao, C. S. (2018). Developing students' writing skills in English - a process approach. Journal for Research Scholars and Professionals of English Language Teaching, 6(2), 1-5.

Elbir, B. ve Bağcı, C. (2013). Birinci ve ikinci kademe okuma eğitimi üzerine yapılan lisansüstü çalışmaların değerlendirilmesi. Adıyaman Üniversitesi Sosyal Bilimler Enstitüsü Dergisi, 6(11), 229-247.

Elbir, B. ve Yıldız, H. (2012). İlköğretim yazma eğitimi üzerine yapılan lisansüstü çalışmalarının değerlendirilmesi. Akademik Bakış Dergisi, 30, 111.

Fareed, M., Ashraf, A. and Bilal, M. (2016). ESL learners' writing skills: Problems, factors and suggestions. Journal of Education and Social Sciences, 4(2), 81-92.

Göçer, A. (2014). Yazma eğitimi. (1. Baskı). Ankara: Pegem.

Göçer, A. ve Arslan, S. (2018). Türkiye' de dil bilgisi öğretimi üzerine hazırlanan lisansüstü tezler hakkında bir meta-analiz çalışması. Kırıkkale Üniversitesi Sosyal Bilimler Dergisi, 8(1), 107-122. 
Göksu, E. (2016). İlköğretim düzeyi yazma becerileri ile ilgili makalelerin ve lisansüstü tezlerin çok yönlü incelenmesi. Yayımlanmamış yüksek lisans tezi. Gazi Üniversitesi, Eğitim Bilimleri Enstitüsü, Sınıf Öğretmenliği Bilim Dalı, Ankara.

Gülen-Canlı, M. ve Tepeli, Y. (2019). Ana dili ve yabancı dil olarak Türkçe eğitimi üzerine eylem araştırması yöntemiyle yapılmış çalışmaların sistematik olarak incelenmesi. Alan Ĕ̆itimi Araştırmaları Dergisi, 5(2), 30-54.

Gündüz, O. ve Şimşek, T. (2016). Anlatma teknikleri-2: Uygulamalı yazma eğitimi el kitabı. (3. Baskı). Ankara: Grafiker.

Güneş, F. (2014). Türkçe öğretimi-Yaklaşımlar ve modeller. (3. Baskı). Ankara: Pegem.

Güneş, F. (2020). Yazmanın temel bileşenleri. B. Bağcı Ayrancı ve A. Başkan (Ed.), Kuram ve uygulamada yazma eğitimi içinde, (1. Bask1), (s. 1-14). Ankara: Pegem.

Gürbüz, S. ve Şahin, F. (2017). Sosyal bilimlerde araştırma yöntemleri. (4. Baskı). Ankara: Seçkin.

Kadıoğlu-Ateş, H. ve Kadıoğlu, S. (2017). Türkiye'de 2005-2015 yılları arasında ilk okuma yazma alanında yapılan lisansüstü çalışmaların değerlendirilmesi. Akademik Sosyal Araştırmalar Dergisi, 5(39), 301-318. DOI: 10.16992/ASOS.11907

Karadağ, R. (2020). Yazma eğitimi. F. Susar Kırmızı (Ed.), İlk ve ortaokullarda Türkçe öğretimi içinde, (2. Baskı), (s. 165-205). Ankara: Anı.

Karagöz, B. ve Şeref, İ. (2020) Yazma becerisiyle ilgili makaleler üzerine bir inceleme: Web of Science veri tabanında eğilimler. Ana Dili Eğitimi Dergisi, 8(1), 67-86.

Karatay, H. (2015). Süreç temelli yazma modelleri: 4+1 planlı yazma ve değerlendirme modeli. M. Özbay (Ed.), Yazma ĕgitimi içinde, (5. Bask1), (s. 21-48). Ankara: Pegem.

Kardaş, M. N., Çetinkaya, V. ve Kaya, M. (2018). 2005-2017 yılları arasında dinleme eğitimi üzerine yapılmış akademik çalışmaların eğilimleri üzerine bir araştırma. Kuram ve Uygulamada Sosyal Bilimler Dergisi, 2(1), 21-32.

Kellogg, R.T. (2008). Training writing skills: A cognitive developmental perspective. Journal of writing research, 1(1), 1-26.

Kellogg, R. T. ve Raulerson, B. A. (2007). Improving the writing skills of college students. Psychonomic Bulletin \& Review, 14(2), 237-242. 
Maden, S. (2011). İsmayıl Hakkı Baltacıŏ̆lu'nun yaz(1)ma eğitimine yönelik düşünceleri ve "Yazının Usûl-i Tedrisi". Turkish Studies, 6(1), 15271542.

MEB. (2019). Türkçe dersi öğretim programı (Illkokul ve ortaokul 1, 2, 3, 4, 5, 6, 7 ve 8. siniflar). Ankara: MEB.

Okasha, M.A ve Hamdi, S. A. (2014). Using strategic writing techniques for promoting EFL writing skills and attitudes. Journal of Language Teaching and Research, 5(3), 674-681.

Orhan-Karsak, H. G. (2020). Yazma eğitimi. E. G. Özenç ve M. Özenç (Ed.), Kuramdan uygulamaya Türkçe öğretimi içinde, (1. Bask1), (s.101-128). Ankara: Pegem.

Öz, M. F. (2011). Uygulamalı Türkçe öğretimi. (4. Baskı). Ankara: Anı.

Özbay, M. (2005). Bilim ve kültür aktarıcısı olarak yazı. Hacettepe Üniversitesi Türkiyat Araştırmaları Dergisi, 2, 67-74.

Özçakmak, H. (2017). Türkçe eğitimi lisansüstü araştırmalarında yeni yönelimler (2011-2015). Uluslararası Türkçe Edebiyat Kültür Eğitim Dergisi, 6(3), 1607-1618.

Özdemir, S. (2018). Okumaya ilişkin lisansüstü araştırmaların eğilimleri. Ana Dili Ĕ̆itimi Dergisi, 6(4), 1161-1178.

Potur, Ö. ve Yıldız, N. (2016). Konuşma becerisi alanında yapılan akademik çalışmaların eğilimleri. Dil ve Edebiyat Ĕ̆itimi Dergisi, 5(18), 27-40.

Sever, S. (2011). Türkçe öğretimi ve tam öğrenme. (5. Baskı). Ankara: Anı.

Sevim, O. ve İşcan, A. (2012). Türkçenin eğitimi ve öğretimi alanında yapılan yüksek lisans tezlerinde geçen anahtar kelimelere dönük bir içerik analizi. Turkish Studies 7(1), 1863-1873.

Şengül, M. (2011). Illköğretim II. kademe Türkçe öğretiminde yazma becerilerine yönelik öğretim ve ölçme-değerlendirme yaklaşımlarının uygulamadaki etkililiğinin değerlendirilmesi. Yayımlanmamış doktora tezi. Fırat Üniversitesi, Eğitim Bilimleri Enstitüsü, Türkçe Eğitimi Ana Bilim Dalı, Elâzığ.

Temizkan, M. ve Erdevir, M. (2020). Yazılı anlatımla ilgili yüksek lisans tezlerinde kullanılan değişkenler üzerine bir değerlendirme. Ana Dili Ĕ̆gitimi Dergisi, 8(4), 1218-1244.

Temur, T. ve Çakıroğlu, A. (2015). Etkinliklerle yazılı ve sözlü anlatım. (3.Baskı). Ankara: Pegem.

Tok, M. ve Potur, Ö. (2015) Yazma eğitimi alanında yapılan akademik çalışmaların eğilimleri (2010- 2014 Yılları). Ana Dili Eğitimi Dergisi, 3(4), 125. 
Topuzkanamış, E. (2014). Yazma stratejileri öğretiminin Türkçe öğretmenliği birinci sinı öğrencilerinin yazılı anlatım başarısı ve yazma kaygısına etkisi. Yayımlanmamış doktora tezi. Gazi Üniversitesi, Eğitim Bilimleri Enstitüsü, Türkçe Öğretmenliği Bilim Dalı, Ankara.

Türkben, T. (2018). Yabancı dil olarak Türkçe öğretimi alanında yapılan lisansüstü çalışmaların değerlendirilmesi. Uluslararası Türkçe Edebiyat Kültür Ĕ̆itim Dergisi, 7(4), 2464-2479.

Uyar, Y. (2016). Yazma becerisini geliştirmeye yönelik araştırmalar: Son çeyrek asrın değerlendirilmesi. Turkish Studies, 11(3), 2273-2294. DOI: 10.7827/TurkishStudies.9479

Varışoğlu, B., Şahin, A. ve Göktaş, Y. (2013). Türkçe eğitimi araştırmalarında eğilimler. Kuram ve Uygulamada Ĕ̆itim Bilimleri, 13(3), 1767-1781.

Yağmur-Şahin, E., Kana, F. ve Varışoğlu, B. (2013). Türkçe eğitimi bölümlerinde yapılan lisansüstü tezlerin araştırma eğilimleri. International Journal of Human Sciences, 10(2), 356-378.

Yaman, E. (2012). Yazma sanatı. (2. Baskı). Ankara: Akçăg.

Yıldırım, A. ve Şimşek, H. (2011). Sosyal bilimlerde nitel araştırma yöntemleri. (8. Baskı). Ankara: Seçkin.

Yılmaz, D. ve Kaya, S. (2020). İlk okuma yazma ve Türkçe öğretimi ile ilgili yazılmış tezlerin incelenmesi. Turkish Studies - Education, 15(1), 443456. DOI: $10.29228 /$ TurkishStudies.40266

Zorbaz, K. Z. (2014). Yazma eğitimi. M. Yılmaz (Ed.), Yeni gelişmeler ışı̆̆ında Türkçe öğretimi içinde, (1. Baskı), (s.109-147). Ankara: Pegem.

\section{Kaynakça Bilgisi / Citation Information}

Kemiksiz, Ö. (2021). Yazma becerilerinin geliştirilmesi üzerine hazırlanan tezlere yönelik bir inceleme: Yarı deneysel çalışmalar. OPUSUluslararası Toplum Araştırmaları Dergisi, 18(41), 3172-3203. DOI: 10.26466/opus.887374. 